\title{
SOCIAL IMPACT INVESTMENT IN LATIN AMERICA: THE ROLE OF GOVERNMENT
}

\author{
Humberto Merritt \\ Instituto Politécnico Nacional (IPN) \\ MEXICO \\ E-mail: hmerritt@ipn.mx \\ https://orcid.org/0000-0003-3580-7325
}

\begin{abstract}
Since 2008 the world has witnessed several profound social transformations that stemmed from the global crisis. As a result, several important actors, such as international agencies, not-for-profit organizations, and big donors, asked for committed attention to financially related societal issues. In particular, they called for more resources targeted to social and community programs, urging investors to adopt more innovative approaches for achieving positive social impacts. Although most of these initiatives originated in developed nations, a growing number of developing countries have been catching up with the trend by proposing policies that suit their needs better. This study analyzes the institutional setting behind Social Impact Investment (SII) for six Latin American countries: Argentina, Brazil, Chile, Colombia, Mexico, and Peru. It aims at answering the following two questions: 1) To what extent is government intervention necessary in encouraging social investment in Latin America? and 2) What tools should national governments use to achieve this goal? This analysis's rationale lies in need to understand alternative approaches for financing social ventures in Latin America since national governments play a leading role in fostering social investments.
\end{abstract}

Keywords: Latin America; Social Impact Investing; Regulation; Institutional Analysis; Government Intervention; Public Policy; Comparative Framework;

\section{INTRODUCTION}

Social Impact Investment (SII) has been praised by non-for-profit organizations, international aid bodies, and private donors as a financial practice that can provide new ways to more efficiently and effectively allocate public and private capital to address social and economic challenges at the global, national and local levels (OECD, 2015).

The interest in encouraging SII stemmed from the 2008 financial crisis when most nations were severely hit by the global economic decline, which had dramatic impacts on the social fabric (Allman and Escobar, 2015; Harji and Jackson, 2012). In the aftermath of the global economic meltdown, some critical players, such as international investment funds, big donors, and corporate investors, came together and decided to harness the power of their funds to address the crisis aftermath and its social and environmental challenges (Bugg-Levine and Emerson, 2011).

Twelve years after the financial crisis, SII has become a well-established financial practice with various studies reporting successful experiences and resulting best practices (Schönherr and Martinuzzi, 2019; UNCTAD, 2018; Wilson, 2016). Despite the main factors underlying success being widely discussed, such as transparency, accountability, and commitment, governments' role in fostering SII has just begun to be studied.

On the other hand, a substantial amount of literature has mainly focused on the United States' situation, and to a lesser degree on the European context, which often differs quite considerably compared to developing country conditions. Consequently, in this study, the role played by 
governments in fostering SII is analyzed and considered, particularly in the context of low- and middle-income Latin American nations.

The rationale for this approach lies in the region's financial system shortcomings. For example, Etchart and Comolli (2013) report that recipients face considerable transaction costs when trying to raise funds for social enterprises (Etchart and Comolli, 2013, p. 129), whereas Abousleiman and Thompson point out that development finance institutions find it challenging to support Latin America's entrepreneurs due to endemic market failures, such as the small size of the financial sector and the lack of sophisticated capital markets (Abousleiman and Thompson, 2018, p. 17). The analysis focuses on Argentina, Brazil, Chile, Colombia, Mexico, and Peru, which are the six largest economies in Latin America, to discuss what aspects of market governance, finance settings, and impact measurement must be considered. By drawing on these cases, this study seeks to understand the dynamics of government intervention in SII, as Latin American policymakers have a role in driving the efficient allocation of social capital as a solution to long-lasting societal and environmental conflicts. The approach is taken here mainly deals with the government's role in setting the regulatory framework for SII. However, a brief examination of private actors involved in SII activities is also provided.

Given that many Latin American countries have been eager adopters of SII, this work aims at answering the following two questions: 1) To what extent is government intervention necessary in regulating social investment?, and 2) What tools should governments use to regulate and stimulate the functioning of SII markets?

The study is structured in eight parts, including the introduction and conclusions. The following section describes the methodology used in this study. The third part defines the concept of Social Impact Investment (SII) that will be used throughout the study. The following part describes the relationship between SII and social entrepreneurship in Latin America. The fifth section deals with SII and the role of the State, and the sixth part introduces the description of policy tools that can be used to promote SII. Finally, the seventh section reports the Latin American experiences with SII. It finishes with a general conclusion, followed by the references used in the study and a short biography of each author.

\section{METHODOLOGY}

Due to the exploratory character of the discussion, the research approach follows a comparative methodology that draws on a desk review of policy documents, specialized books, consultancy reports, and research articles dealing with SII. The investigation was carried out by identifying and retrieving some of the most frequently cited works within this topic for a deep understanding of SII best practices.

We also gained access to policy-making design experiences in these countries by reviewing previous research findings. A comparative framework could be developed to analyze the six selected Latin American cases from these insights. However, a caveat is in order. Although the standard rules for checking the relevant literature were followed, Gaye Tuchman's advice needs to be taken into consideration: "some articles or books that have made major contributions may not be cited very much, because they are in a very specialized area" (Tuchman, 1994, p. 319).

Next, the concept of SII is defined as a background for the analytical framework that follows.

\section{DEFINING SOCIAL IMPACT INVESTMENT}

Defining SII is crucial for advancing the role governments can play in fostering its financial procedures. In this regard, a growing body of literature uses terms such as corporate social responsibility (CSR), community programs, charitable giving, donations, socially responsible 
investments, and/or social contributions to approach the SII practice (Allman and Escobar, 2015; Herman, 2010; KPGM, 2014; Nicholls, 2010). From the perspective of this study, governments can act as a driver for social and environmental change by providing incentives for organizations to engage in any of these schemes.

According to Harji and Jackson (2012), four factors converged to generate corporations' interest in SII: 1) broader considerations of risk in investment decisions, triggered by the financial crisis; 2) growing recognition that existing resources are insufficient to address severe poverty, inequality, environmental destruction, and similarly highly complex global issues; 3) an emerging set of actions demonstrating that it is possible to finance scalable business models that create social and environmental value; and 4) the transfer of wealth from a generation of high net worth individuals seeking to embed their moral values in the allocation of their capital Harji and Jackson (2012, p. $10)$.

In the case of the developing world, the SII financial practice can help achieve diverse societal outcomes (Kappen et al., 2019; Wilson, 2016). In particular, the SII approach can help developing countries' civil organizations address social and/or environmental needs with the explicit expectation of measurable social and financial returns (OECD, 2019b).

SII can also bring greater effectiveness, innovation, accountability, and scale for the pursuit of broader development goals (LAVCA, 2018; UNCTAD, 2018; Wilson 2016), such as the sustainable development agenda (Addis Ababa Action Agenda), formally established in Ethiopia in July 2015, when several development agencies organized the Third International Conference on Financing for Development (OECD, 2015).

However, the success of the SDG agenda requires the State's commitment to incentivize private financing (Fine, Pandit, Hickson, and Tuinenburg, 2018). Moreover, as SII gathers pace, the State's role in consolidating remains relatively unexplored. In this regard, several studies have suggested that governments should promote ad-hoc institutional mechanisms to help SII markets develop. Most of these recommendations focused on two areas: 1) the establishment of regulatory rules that ease SII governance (Addis, 2016; Nicholls, 2010; Wiggan, 2018; Wilson, 2016); and 2) and the generation of metrics and standards to measure SII (Bugg-Levine and Emerson, 2011; Calderini et al., 2017; Fine et al., 2018). The following section provides a more detailed analysis of these issues.

\section{SOCIAL IMPACT INVESTMENT AND SOCIAL ENTREPRENEURSHIP IN LATIN AMERICA}

The Latin America and the Caribbean (LAC) region is a relatively homogeneous territory, which was growing at an astonishing pace until recently. However, the collapse of commodity markets has severely hit its exports of raw materials (ECLAC, 2019).

As a result, the region now faces increasing challenges to continue making progress on the social front as it did in the first decade and a half of the new century. Yet, several studies suggest that LAC badly needs massive infrastructure investments to close the development gap (Abousleiman and Thompson, 2018; ECLAC, 2019; OECD, 2019a).

To better understand the size and complexity of the LAC region, Table 1 shows some critical social indicators. 
Table 1 Selected social indicators for Latin America, 2017

\begin{tabular}{|l|c|c|c|c|c|c|c|}
\hline Country & Populatn a & $\begin{array}{c}\text { Gross } \\
\text { Domestic } \\
\text { Product b }\end{array}$ & $\begin{array}{c}\text { Gross } \\
\text { Domestic } \\
\text { Product per } \\
\text { capita c }\end{array}$ & $\begin{array}{c}\text { Human } \\
\text { Capital } \\
\text { Index d }\end{array}$ & $\begin{array}{c}\text { Poverty } \\
\text { Headcount } \\
\text { Ratio e }\end{array}$ & $\begin{array}{c}\text { Adult } \\
\text { Female } \\
\text { Literacy } \\
\text { Rate f* }\end{array}$ & $\begin{array}{c}\text { Automated } \\
\text { Teller } \\
\text { Machines g }\end{array}$ \\
\hline Argentina & 44.3 & 637.4 & $14,398.4$ & 0.61 & 7.1 & 99.1 & 59.4 \\
\hline Belize & 0.4 & 1.9 & $4,971.2$ & n.a. & n.a. & n.a. & 38.9 \\
\hline Bolivia & 11.1 & 37.5 & $3,394.0$ & n.a. & 24.7 & n.a. & 40.2 \\
\hline Brazil & 209.3 & $2,055.5$ & $9,821.4$ & 0.56 & 21.0 & n.a. & 106.8 \\
\hline Chile & 18.1 & 277.1 & $15,346.4$ & 0.67 & 6.4 & n.a. & 53.0 \\
\hline Colombia & 49.1 & 314.5 & $6,408.9$ & 0.59 & 27.6 & 94.9 & 41.8 \\
\hline Costa Rica & 4.9 & 57.3 & $11,677.3$ & 0.62 & 9.7 & n.a. & 64.9 \\
\hline Ecuador & 16.6 & 104.3 & $6,273.5$ & 0.60 & 23.2 & 93.3 & 50.3 \\
\hline El Salvador & 6.4 & 24.8 & $3,889.3$ & 0.50 & 29.0 & 86.3 & 37.3 \\
\hline Guatemala & 16.9 & 75.6 & $4,471.0$ & 0.46 & n.a. & n.a. & 36.1 \\
\hline Guyana & 0.8 & 3.6 & $4,655.1$ & 0.50 & n.a. & n.a. & 20.3 \\
\hline Honduras & 9.3 & 23.0 & $2,480.1$ & 0.49 & 52.6 & 88.9 & 23.9 \\
\hline Mexico & 129.2 & $1,150.9$ & $8,910.3$ & 0.61 & n.a. & 94.0 & 53.5 \\
\hline Panama & 4.1 & 62.3 & $15,196.4$ & 0.53 & 14.1 & n.a. & 70.7 \\
\hline Paraguay & 6.8 & 39.7 & $5,823.8$ & 0.53 & 18.6 & 93.8 & 27.1 \\
\hline Peru & 32.2 & 211.4 & $6,571.9$ & 0.59 & 23.9 & 91.2 & 106.6 \\
\hline Suriname & 0.6 & 3.0 & $5,317.4$ & n.a. & n.a. & n.a. & n.a. \\
\hline Uruguay & 3.5 & 56.2 & $16,245.6$ & 0.60 & 2.9 & 98.8 & 84.7 \\
\hline Venezuela & 32.0 & n.a. & n.a. & n.a. & n.a. & 97.2 & n.a. \\
\hline LAC & 644.1 & $5,974.2$ & $9,274.8$ & n.a. & n.a. & 93.1 & 42.5 \\
\hline Source: & 1 & 1.9 & & & & \\
\hline
\end{tabular}

Source: World Bank World Development Indicators, available at https://bit.ly/3omu6QB

Notes a: Total Population (million people). b: Gross Domestic Product (GDP) (Billion current US\$). c: GDP per capita (current US\$). d: Human Capital Index (HCI) (scale 0-1). e: Poverty Headcount Ratio at $\$ 5.50$ a day (\% of the population). $f$ adult female literacy rate (AFLR) (\% of females aged 15+). g: Automated teller machines (ATMs) (per 100,000 adults) *: Data from 2016. n.a.: data not available

In this chapter, the cases of Argentina, Brazil, Chile, Colombia, Mexico, and Peru are considered because they accounted for almost 78 percent of the region's gross domestic product (GDP) in 2017. They are not a homogenous group, though. Social indicators from Table 1 show considerable differences among the six nations. For example, Chile exhibits the highest Human Capital Index in our set (0.67), whereas Brazil has the lowest (0.56). Argentina and Chile are considered middleincome countries regarding GDP per capita, whereas Colombia and Peru have less than half of that income per habitant. Finally, Brazil and Peru have the highest rate of automated teller machines (ATMs) in the group, and quite surprisingly, Chile and Mexico, both members of the OECD club, have the lowest rate of ATMs in the group.

Traditionally, most LAC governments have relied upon a mix of external debt and public funds to meet infrastructure demands. Still, these resources are now not enough to fill the growing gap. Not surprisingly, then, LAC has made considerable strides in attracting private sector investments in infrastructure. According to Abousleiman and Thompson (2018), the region has the largest stock of active Public-Private Partnerships (PPP) investments and the largest pipeline of infrastructure projects by volume globally, reflecting the central role of the private sector in the regional development agenda (Abousleiman and Thompson, 2018, p. 7).

On the other hand, there have been several recent developments in global SII, including an increased number of initiatives with a wide range of specific social and environmental impacts taking place in several countries around the region. For example, Etchart and Comolli (2013) report programs for promoting social enterprise networks in Argentina, Brazil, Chile, and Peru, whereas 
Leme et al. (2014) analyze the growing presence of private actors, such as grant providers and angel investors in Brazil. For her part, Wilson (2016) discusses the SII that a social venture fund (Acumen) is doing in water, health, housing, energy, agriculture, and education in Colombia.

Additional (and more recent) SII proposals are worth examining too. For example, the Association for Private Capital Investment in Latin America (LAVCA) has reported the 2016-2017 results on private investing practices in LAC: 1 ) total assets under management allocated to SII are estimated to be the U.S. $\$ 4.7$ billion, 2) 55 investors reported making investments deploying total capital of U.S. \$1.4 billion through 860 investments, and 3) The most significant sectors for investment were microfinance (U.S. \$782M, 369 deals) and agriculture (U.S. \$300M, 276 deals), together representing $75 \%$ of the total capital deployed in the region (LAVCA, 2018, p. 9). What these cases show, however, is the relatively weak role of public support for private initiatives regarding SII.

This point is worth stressing because the LAC region has made considerable strides in attracting private funds for SII. Yet, SII exhibits different levels of development across the region, with Argentina, Brazil, Colombia, Mexico, and Peru accounting for the lion's share of impact investments (OECD 2019b, p. 118). Table 2 shows the patterns of social investments reported in the six largest Latin American economies between 2014 and 2017.

Table 2 Impact investment in Latin America, 2014-2017

\begin{tabular}{|l|c|c|c|c|}
\hline \multirow{2}{*}{ Countries } & \multicolumn{2}{c|}{ Total Invested (million US\$) } & \multicolumn{2}{c|}{ Number of Deals } \\
\cline { 2 - 5 } & $\mathbf{2 0 1 4 - 1 5}$ & $\mathbf{2 0 1 6 - 1 7}$ & $\mathbf{2 0 1 4 - 1 5}$ & $\mathbf{2 0 1 6 - 1 7}$ \\
\hline Argentina & NA & 66 & NA & 20 \\
\hline Brazil & 69 & 131 & 48 & 69 \\
\hline Chile & 1 & 9 & 3 & 9 \\
\hline Colombia & 33 & 86 & 16 & 42 \\
\hline Mexico & 65 & 169 & 23 & 108 \\
\hline Peru & 210 & 218 & 52 & 152 \\
\hline Rest of LAC & 574 & 765 & 187 & 460 \\
\hline Total & 952 & 1,444 & & 860 \\
\hline
\end{tabular}

Source Author's analysis and elaboration based on OECD, 2019b, p. 119

From Table 2, we see how LAC social investments grew 51.7 percent from 2014 to 2017, whereas deals grew three hundred times within the same period. A closer examination of the reported OECD figures allows us to state that the average agreement shrank from the U.S. \$5.1 million to 1.7 million during those years. However, it is not clear for us the reasons behind this contraction. Yet, LAVCA (2018) reports a median average deal of U.S. \$900,000 between 2016 and 2017, which is an even more petite figure than that reported by the OECD, despite the growing SII commitments that LAVCA surveyed from investors (LAVCA, 2018, p. 20).

This work argues that SII is directly related to social entrepreneurship, so governments have a role in fostering entrepreneurship and economic growth through SII markets. As pointed out by ECLAC (2019), access to financial services can substantially affect welfare by reducing poverty because it facilitates savings, reduces the dependence on informal, more expensive financing sources, and increases productive investments. Still, entrepreneurialism is scarcely practiced by Latin Americans (Etchart and Comolli, 2013).

Being entrepreneurship at the center of SII is worth examining its situation in LAC. The Global Entrepreneurship and Development Institute produces the Global Entrepreneurship Index (GEI), which measures the health of entrepreneurial ecosystems in 137 countries. According to Acs and colleagues (2019), the most entrepreneurial country in the LAC region in 2019 was Chile, scoring 58.8 out of 100 points. Chile leads the region in topics such as risk acceptance and product 
innovation. It was followed by Colombia and Uruguay, with 34.1 and 30.1, respectively. Interestingly, Colombia stands out in high growth and Uruguay in product innovation. Table 3 depicts the GEI rankings from 2019 and 2018 and its performance between 2018 and 2019 for eighteen LAC nations.

Table 3 Global entrepreneurship index for selected Latin American nations, 2018-19

\begin{tabular}{|l|c|c|c|}
\hline \multicolumn{1}{|c|}{ Country } & Score 2018 & Score 2019 & Variation \\
\hline Chile & 58.5 & 58.3 & -0.2 \\
\hline Colombia & 38.2 & 34.1 & -4.1 \\
\hline Uruguay & 35.0 & 30.1 & -4.9 \\
\hline Costa Rica & 33.3 & 28.8 & -4.5 \\
\hline Peru & 28.4 & 27.7 & -0.7 \\
\hline Mexico & 26.4 & 27.1 & 0.7 \\
\hline Argentina & 24.0 & 26.0 & 2.0 \\
\hline Panama & 27.7 & 25.5 & -2.2 \\
\hline Dominican Republic & 24.3 & 23.6 & -0.7 \\
\hline Bolivia & 20.4 & 22.1 & 1.7 \\
\hline Guatemala & 18.5 & 18.7 & 0.2 \\
\hline Ecuador & 20.5 & 18.5 & -2.0 \\
\hline Honduras & 18.7 & 17.2 & -1.5 \\
\hline Paraguay & 18.7 & 16.6 & -2.1 \\
\hline Brazil & 20.3 & 16.1 & -4.2 \\
\hline Nicaragua & 14.7 & 16.1 & 1.4 \\
\hline El Salvador & 16.7 & 15.7 & -1.0 \\
\hline Venezuela & 13.8 & 13.1 & -0.7 \\
\hline
\end{tabular}

Source: The Global Entrepreneurship Institute, available at https://bit.ly/3G7Ast6

Table 2 indicates that Mexico, Argentina, Bolivia, Guatemala, and Nicaragua improved their scores, while the rest declined. Mexico improved in networking and had opportunities in risk capital (Acs et al., 2019, p. 52). LAC's poor scoring in global entrepreneurship weakens social entrepreneurship too. In this regard, Etchart and Comolli (2013) have identified six key barriers to the promotion of social entrepreneurship in Latin America: 1) a lack of entrepreneurial culture, 2) limited access and use of information technologies, 3) growth restriction for small and expanding companies, 4) lack of skill development, 5) limited networks, and 6) limited access to financing (Etchart and Comolli, 2013, p. 14). Overcoming these barriers calls for the intervention of the State, as we shall see next.

\section{SOCIAL IMPACT INVESTMENT AND THE ROLE OF THE STATE}

The Organisation for Economic Co-Operation and Development (OECD) has pointed out that the State has a key role in the Impact Investing ecosystem in the setting of the right enabling environment conditions (OECD, 2015, p. 12).

The OECD also points out that, under ideal conditions, policy-making should unfold as a step-bystep chronological process, where public authorities firstly determine the role the government wants to play based on the maturity of the SII market, secondly by identifying the needs expressed by service providers and end beneficiaries, thirdly by setting the policy objectives in alignment with the political agenda, then by selecting the most appropriate type of intervention and instrument, fifthly by allocating the necessary resources for implementation and finally, by designing the delivery mechanism (OECD, 2019b, p. 159). Therefore, by fostering SII, the government can encourage privately-owned financing into emerging economies by taking 
advantage of proven experiences, policies, and methodologies from the developed world (Kappen et al., 2019; Wilson, 2016).

However, it is essential to consider that there exists a complex interplay between social development and financial profitability. In this respect, the OECD (2015) has also pointed out that markets are structured to determine the role and mix of public and private capital and, therefore, the potential part of SII (OECD, 2015, p. 12).

In particular, Rosemary Addis argues that governments have three roles to play concerning SII (Addis, 2016). First, as a market participant, capturing new ideas and practices and adapt old ones that provide better solutions to social and economic problems and identify opportunities more effectively to target and leverage public spending by attracting private capital. Second, as a market builder, by catalyzing social finance to encourage the market to grow, enabling new or existing ventures better placed than government to develop and deliver community-based solutions, and enlarging the pool of capital seeking to achieve positive benefits for society. Third, as a market steward, by stewarding the field of social finance, ensuring appropriate regulation, removal of barriers to action, and creating the conditions for replication and scale of what works (Addis, 2016, p. 395).

A thorough review of OECD's work globally was used to devise a diagram that depicts the SII ecosystem. Its purpose is to identify the interrelations that impact-driven organizations, intermediaries, and investors have established with the SII milieu. Figure 1 illustrates the main participants of the SII ecosystem. The framework helps to identify the set of interrelations that SII actors have established with each other. Figure 1 shows how public bodies (including international agencies) can work with private and institutional investors to support the SII ecosystem. 
Fig. 1 The SII institutional framework

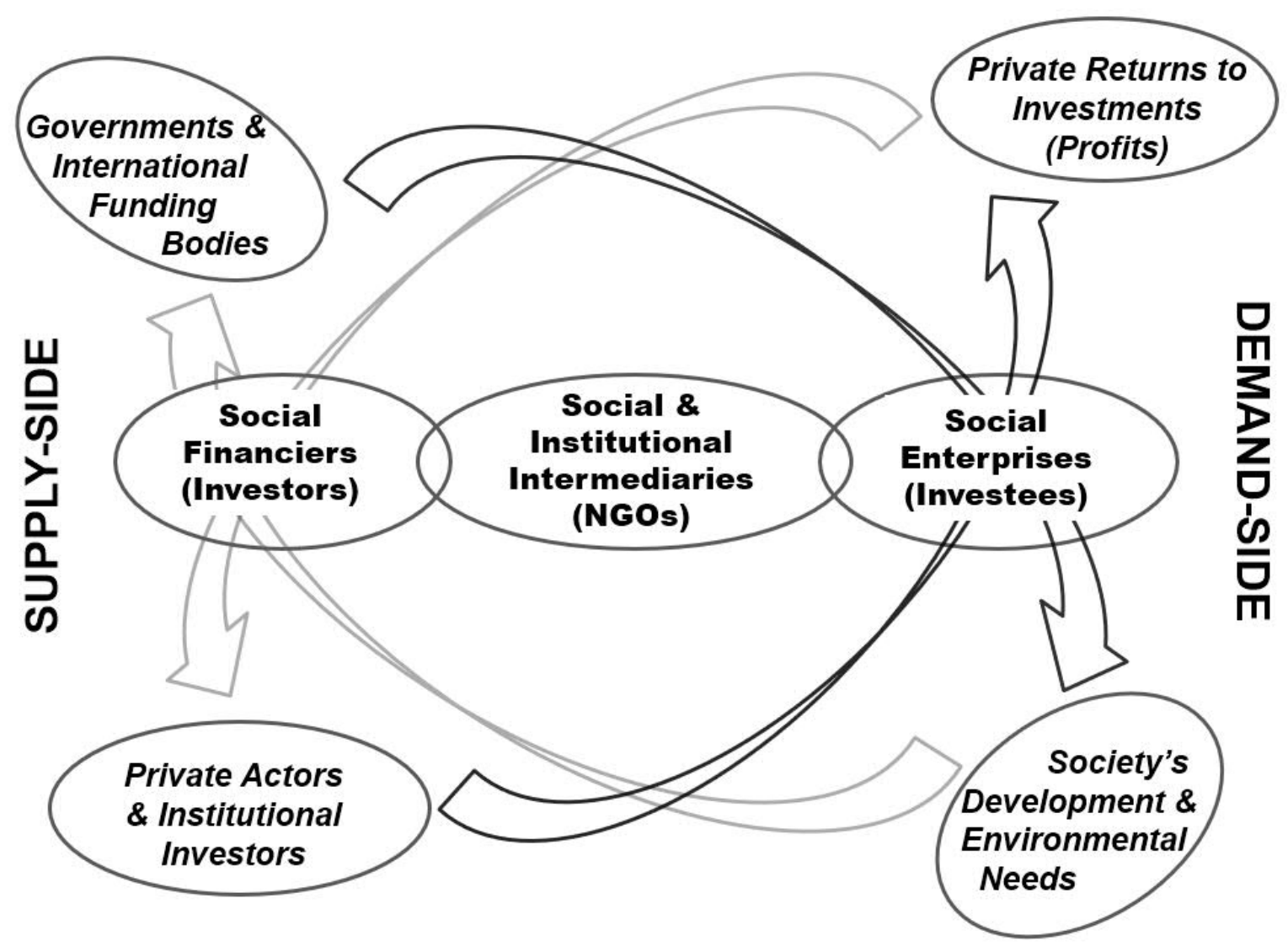

Source: Author's elaboration.

The above SII framework has three main components. The first deals with the supply side, which involves the investors. The second comprehends the demand side, which embraces the SII recipients or investees, and the third includes social and institutional intermediaries. Their role is to serve as a platform between supply and demand to facilitate the linkage between investors and investees. We need to comment that no one can expect, from our framework, that the government is called to supplant private investors by directly funding SII, for example.

There is an additional implicit assumption regarding the flux of information. Financial data is considered generally available and (preferably) widely diffused because investors (either private donors or corporate funds) wanting to initiate SII projects with investees (e.g., social enterprises) must know what the expected returns are. In contrast, social entrepreneurs may wish to see if they can depend on private funding when launching their SII projects.

In Figure 1, intermediaries might address these requirements once they have access to the relevant financial information. However, getting the appropriate data is neither easy nor cheap. As such, governments have a role in encouraging financial data availability to counteract asymmetric information. As Allman and Escobar (2015) have pointed out, as the frequency and depth of information exchange increases, both parties need to understand the commitment that each brings to the process. 
Calderini and his colleagues (2017) stressed the relevance of widely available financial information. In particular, they argue that financial information asymmetry tends to harm mainly developing country SII markets. They reckon that information asymmetry stems from the following factors: problems with market size estimation, SII market small and immature SII market in evolution, absence of track records, flawed methodological approaches, and defective measurement standards (Calderini et al., 2017, p. 81).

As mentioned above, poor financial education in the LAC region constitutes a critical barrier to financial inclusion by limiting informed decisions essential to the expansion of financial services. Besides, financial restrictions on social entrepreneurship are worsened by enduring institutional weaknesses, socio-economic inequalities, and poor education. In Mexico, for example, corruption and weak law enforcement lead companies to seek collective development goals by relying on philanthropic activities; whereas, in Brazil, the private sector encourages socially responsible initiatives because firms are expected to provide social services, which strongly reinforce their brand reputation (Forcadell and Aracil 2017, p. 387).

The following section introduces a regulatory proposal for the role of the government in SII markets, which draws on the work developed by Rosemary Addis (2016).

\section{POLICY TOOLS FOR PROMOTING SOCIAL IMPACT INVESTMENTS}

The 2008 crisis prompted debates that served to emphasize the importance of SII in dealing with currently critical social issues, such as climate change and sustainable development goals (Schönherr and Martinuzzi, 2019). In many discussions, the underlying goal was to define the

government's role in encouraging SII. For example, Thornley and colleagues (2011) argued that government could participate directly in the market or influence impact investing through policy or regulation (Thornley et al., 2011, p. 8). However, most of the analyses from the financial crisis debate were devised for industrialized nations. Therefore, the role of governments in encouraging SII has received considerably less attention in the developing world.

Hence, we argue that the State can help foster the creation and regulation of SII markets in Latin America by harnessing the several policy tools available. Australian and German scholars have mainly discussed the State's regulatory role. For example, Black (2016) has pointed out that clarification of regulation would help facilitate market development in Australia (Black, 2016, p. 119). In contrast, Glänzel and Scheuerle (2016) argue that there is a role for the government to play in setting adequate mechanisms for investments among intermediary organizations in Germany (Glänzel and Scheuerle, 2016, p. 1645).

In the case of Latin America, institutions typically lack the operational capacity to foster and regulate social, financial investments (Abousleiman and Thompson, 2018). In this regard, the work of Rosemary Addis (2016) on the role of government in restoring trust in financial markets in the aftermath of the 2008 crisis is worth considering. In particular, she suggests four institutional requirements for the successful setting of social finance markets: 1) the creation of confident and informed demand, 2) the efficient matching of supply and demand, 3) the availability of several different investment mechanisms, and 4) a resilient supply of finance (Addis, 2016, p. 398).

Indeed, the 2008 crisis changed several paradigms regarding the functioning of capital markets. For example, before the crisis, traditional market failure theory was used to deal with some shortcomings, such as non-market barriers to investment, information asymmetries, the uncertainty surrounding market development, and the restraints to the free-market operation. It now seems incapable of restoring market requirements under the enlarged social conditions due to the need for better policy tools (Addis 2016; Wiggan, 2018). 
Besides, SII poses new challenges to enterprises, funders, and policymakers alike. The reason is that SII markets privilege the achievement of social goals over private ones, thus rendering obsolete traditional financial benchmarks. In particular, Addis (2016) proposes a suite (or toolbox) of policy options that governments can use to address SII promotion and regulation. Her approach acknowledges the role of government as standard setter and funder but recognizes that there is more than money and law to contribute (Addis 2016, p. 407).

Although Addis' approach has received considerable attention, Fox and his colleagues (2002) were among the first to describe the roles of public policy in promoting and fostering social, financial markets. According to these authors, public sector agencies have played an essential part in providing an enabling environment for corporate social responsibility (CSR) through the following roles: 1) mandating, 2) facilitating, 3) partnering and 4) endorsing (Fox et al., 2002, p. iii). In the case of Addis (2016), a government can facilitate the development of the market through any means, such as providing a supportive environment; taking a longer-term view of its development; convening and encouraging collaboration across sectors, and designing and implementing innovative policies to challenge both social economy organizations and investors to take up new financing options. These scholars share the same position regarding the importance of setting appropriate policy tools to encourage SII.

In our case, we will take advantage of Addis' approach to adapt it to the topic of Latin America. Table 4 shows our adaptation of Addis' conceptual framework for public policy by highlighting some aspects of the sequence Mandate $=>$ Enable $=>$ Partner $\Rightarrow$ Endorse.

Table 4 - Policy tools available for supporting SII markets

\begin{tabular}{|c|c|c|c|}
\hline Mandate & Enable & Partner & Endorse \\
\hline $\begin{array}{l}\text { Command and } \\
\text { control legislation }\end{array}$ & Enabling legislation & Combining resources & Political support \\
\hline Regulators & Creating incentives & $\begin{array}{l}\text { Stakeholder } \\
\text { engagement }\end{array}$ & Publicity and praise \\
\hline $\begin{array}{l}\text { Legal and fiscal } \\
\text { penalties and rewards }\end{array}$ & Capacity building & $\begin{array}{l}\text { Linking agents by } \\
\text { dialogue }\end{array}$ & \\
\hline & $\begin{array}{l}\text { Funding support } \\
\text { Raising awareness } \\
\text { Stimulating markets }\end{array}$ & & \\
\hline
\end{tabular}

Source: Author's elaboration based on Addis (2016), p. 407.

Addis's framework distinguishes several more intricate tools to apply to the Latin American context. For instance, penalties and rewards are generally established through political agreements, so they are dependent on a regime's political agenda, which means that progressive policymakers tend to favor SII in contrast with more conservative officials who are reluctant to endorse interventionist policies (OECD, 2019a, p. 26). Therefore, the current challenge is developing policy and using the toolbox in individual jurisdictions to stimulate social finance, particularly in a globalizing economy (Addis 2016, p. 407).

In this regard, Addis has pointed out that local context in social finance goes beyond the usual role of the State in social service delivery (Addis, 2016, p. 398), and the development of SII markets in Latin America calls for the government to employ meticulous planning, sound regulation, and tailored institutional frameworks, the implementation of which requires a broad consensus to be effective because regional differences are significant and need to be addressed by specific policies. Some of these conditions are reviewed in the following section. 


\section{LATIN AMERICAN EXPERIENCES IN SOCIAL IMPACT INVESTMENT}

Latin America has long been a traditional recipient of foreign direct investment (FDI) financial assets. The OECD reports that FDI has shown an average of 4 percent of the region's GDP from 2005 to 2019 (OECD, 2019a, p. 53). However, regional financial markets are still weak and underdeveloped (Abousleiman and Thompson 2018; Forcadell and Aracil 2017). As a result, social investments tend to be rare and small in proportion to the region's economic potential (EIU 2019; Etchart and Comolli 2013). The existing impact investors come primarily from outside the area (LAVCA, 2018, p. 14).

Nevertheless, there has recently been growing interest in funding social ventures in Latin America. For instance, Paul Herman acknowledges the positive impact that enterprises such as Compartamos.com, a publicly listed microfinance and banking institution, have had in Mexico (Herman, 2013, p 61). The Economist Intelligence Unit (EIU) reports that Latin America remains the region with the most conducive regulatory and policy environment for financial inclusion, claiming that Colombia, Peru, and Uruguay maintained their rankings at the top of the 2019 EIU Microscope by improving their overall scores, as well as their scores for specific domains (EIU, 2019, p. 5).

On the other hand, not-for-profit organizations (NFPO) have traditionally been active in the LAC region. To some extent, NFPO has taken care of social challenges that free markets have not yet solved (Etchart and Comolli, 2013). It is worth stressing the role these organizations have played in developing the social fabric where budget restrictions affect the government's response capacity to reach impoverished communities to alleviate their local needs (Leme et al., 2014). In many cases, NFPO has functional advantages such as an appropriate supply of specialized staff and ad-hoc physical resources to assist these communities far more quickly and effectively than governmental agencies (Etchart and Comolli, 2013).

An interesting case is Ashoka, which has played a prominent role in assisting Brazil's rural and urban impoverished communities. Ashoka's work has been widely acknowledged.

Despite the active role of NFPO, SII markets in Latin America have not yet received the corresponding impulse, especially in terms of the emergence of profit-oriented social endeavors. One reason for the relative lack of profit-oriented social firms is the distorting effect of flawed policy interventions in financial markets. In this respect, the OECD has reported the endemic weakness of Latin American financial markets, which tends to produce rising borrowing costs when international conflicts emerge (OECD, 2019a, p. 47).

Higher borrowing costs inhibit any potential entrepreneur from taking risks. This condition is more pressing for social entrepreneurs given the additional structural restrictions they must face, such as lower profit margins and more extended time frames to recover their initial investments (Etchart and Comolli, 2013, p. 104).

Although borrowing costs can be lowered through banking competition, Latin America is characterized by an oligopolistic market structure in its financial sector (Forcadell and Aracil 2017). As a result, social entrepreneurship is rarely seen as a priority for these institutions. In this regard, the OECD has stressed that further efforts are needed to increase financial inclusion (OECD, 2019a, p. 143).

However, Latin American policymakers have preferred to orientate their efforts in reinforcing the role of intermediaries such as public offices and quasi-governmental bodies. In this respect, we have reviewed the main policy actions that have been put in place to attract SII investments during the last few years in the six LAC nations, as Table 5 reports. 
Table 5 - Examples of public policy actions taken in Latin America to attract SII

\begin{tabular}{|c|c|c|}
\hline Country & Public Policy Actions & Policy Results \\
\hline Argentina & $\begin{array}{l}\text { Two main actions: the creation of the Financial } \\
\text { Inclusion Coordinating Committee; the enacting } \\
\text { of the law on productive financing }\end{array}$ & $\begin{array}{l}\text { Policy outcomes are still } \\
\text { pending to be confirmed. }\end{array}$ \\
\hline Brazil & $\begin{array}{l}\text { Established a national association focused on } \\
\text { creating large networks of financial agents, } \\
\text { seeking to promote technological and digital } \\
\text { education }\end{array}$ & $\begin{array}{l}\text { The country's substantial } \\
\text { urban middle class has helped } \\
\text { to attract SII, but the } \\
\text { conjunction of political and } \\
\text { economic risks, combined } \\
\text { with rising interest rates, } \\
\text { disincentivized investors }\end{array}$ \\
\hline Chile & $\begin{array}{l}\text { Established a national commission focused on } \\
\text { encouraging financial inclusion by offering } \\
\text { relevant information for both the supply and } \\
\text { demand sides }\end{array}$ & $\begin{array}{l}\text { Despite its traditional } \\
\text { openness to foreign } \\
\text { investments, the lack of a } \\
\text { comprehensive overall } \\
\text { strategy, along with non- } \\
\text { interventionist policies, have } \\
\text { been ineffective so far in } \\
\text { consistently attracting social } \\
\text { investments }\end{array}$ \\
\hline Colombia & $\begin{array}{l}\text { Financial inclusion is encouraged by an inter- } \\
\text { institutional committee, which coordinates the } \\
\text { interaction between the government's offices and } \\
\text { the private sector in areas such as financial } \\
\text { inclusion and education }\end{array}$ & $\begin{array}{l}\text { The country's socially funded } \\
\text { initiatives are still in the } \\
\text { formative stage, narrowing } \\
\text { the possibilities for more } \\
\text { substantial commitments }\end{array}$ \\
\hline Mexico & $\begin{array}{l}\text { The National Council of Financial Inclusion } \\
\text { (CONAIF) pushes for actions related to the } \\
\text { promotion of interest-free microcredits, the } \\
\text { modernization of state-owned development } \\
\text { banks and the introduction of an electronic } \\
\text { payment system }\end{array}$ & $\begin{array}{l}\text { The majority of socially } \\
\text { based firms are small and } \\
\text { hence face more challenging } \\
\text { conditions to raise capital and } \\
\text { attract high-quality talent }\end{array}$ \\
\hline Peru & $\begin{array}{l}\text { Developed two initiatives to promote financial } \\
\text { inclusion: the Multisectoral Commission on } \\
\text { Financial Inclusion, and the National Strategy for } \\
\text { Financial Inclusion (ENIF) }\end{array}$ & $\begin{array}{l}\text { The SII market looks } \\
\text { promising but structural } \\
\text { problems, such as vast } \\
\text { income inequality, poverty, } \\
\text { quality of education, informal } \\
\text { work and unemployment, } \\
\text { tend to hold back its potential }\end{array}$ \\
\hline
\end{tabular}

Source: Author's elaboration based on desk review.

A common feature that the six nations share in their policies is a top-down approach. The action originated in a central office and then applied to a specific situation. So, according to the evidence depicted above, all six LAC nations have had a minimal impact on promoting social investment. Furthermore, policy tools have been ineffective in solving pressing social needs given the persistent scarcities (ECLAC, 2019, p. 26). 
By drawing on Addis' framework (Addis, 2016, p. 429), we can explain these failures by suggesting that Latin American countries lack practical tools to measure the efficacy of their SIIoriented programs. As discussed above, we believe that the priority for many LAC governments has been in achieving short-term, narrowly focused goals rather than in devising far-reaching applications, such as leveling the playing field through lowering competition barriers and enhancing social entrepreneurship.

The six nations need to develop social finance impact frameworks more comprehensively to encourage SII markets. For example, by harnessing their institutional potential to summon all relevant agents to help them inform (and measure) their decision-making. These actions can be seen as forming part of the enabling policy tools at their disposition (see Table 4, above).

However, these actions can have a limited effect because the measurement of social prosperity and welfare creation resulting from SII is not yet well-developed. In this case, many studies have pointed out that reliable methods for measuring value creation are still rare (Nicholls et al., 2016; Schönherr and Martinuzzi, 2019; OECD, 2019b; Wiggan, 2018).

Because of these shortcomings, one plausible alternative is to develop socially-oriented projects where policy tools can be applied to foster SII. Table 6 presents a sequence of actions for setting a socially-oriented investment project, which policymakers could use as an example. Our scheme draws on the work of Cole, Gandhi and Brumme (2018), who have theorized about the kind of metrics that could facilitate investors' assessments of potential opportunities. We present this exercise to contrast their variables with the already reviewed literature.

Table 6 Sequential stages for investments oriented towards social goals

\begin{tabular}{|l|l|l|}
\hline \multicolumn{1}{|c|}{ Stage } & \multicolumn{1}{|c|}{ Conditions to meet } & \multicolumn{1}{c|}{ Requirements from investors } \\
\hline Input & $\begin{array}{l}\text { Level of resources that are deployed in service } \\
\text { of a specific set of activities }\end{array}$ & $\begin{array}{l}\text { Capital deployed as an initial } \\
\text { investment (Impact Capital) }\end{array}$ \\
\hline Activity & $\begin{array}{l}\text { Actions and tasks that are performed in support } \\
\text { of specific impact objectives }\end{array}$ & $\begin{array}{l}\text { Activities are undertaken to } \\
\text { deliver on impact goals }\end{array}$ \\
\hline Output & $\begin{array}{l}\text { Tangible practices, products, and services that } \\
\text { result from the activities that are undertaken }\end{array}$ & $\begin{array}{l}\text { Services rendered through the } \\
\text { impact capital provided }\end{array}$ \\
\hline Impact & $\begin{array}{l}\text { Changes, or effects, on individuals or the } \\
\text { environment that follow from the delivery of } \\
\text { products and services }\end{array}$ & $\begin{array}{l}\text { Income } \\
\text { beneficiaries due to impact } \\
\text { capital }\end{array}$ \\
\hline $\begin{array}{l}\text { Changes, or effects, on society or the } \\
\text { environment that follow from outcomes that } \\
\text { have been achieved }\end{array}$ & $\begin{array}{l}\text { Impact on society due to impact } \\
\text { capital }\end{array}$ \\
\hline
\end{tabular}

Source: Authors' elaboration based on Cole et al. (2018), p. 10.

It must be stressed that external and internal factors may still influence SII considerations during the policy decision process. For instance, the OECD distinguishes between triggering and hindering factors (OECD, 2019b, 160). Among the former are those that change community expectations about the role of government and the financial sector in funding social service delivery. In contrast, the latter is exemplified by situations such as the fear of privatization in the delivery of public services, weak business and financial culture within public administrations, obstacles to dialogue with investors and enterprises, lack of awareness and/or policymakers' understanding of market mechanisms, weak monitoring capacity around social and environmental priorities. In the case of Latin America, hindering factors can be extremely important when 
designing SII policies in view of the region's tendency for exacerbated responses to social and political conflicts (ECLAC, 2019).

We close this section by stressing that LAC governments can command powerful economic forces to foster SII markets. In particular, we believe that the primary role of governments in promoting the SII ecosystem lies in leveling the playing field for social entrepreneurship. One way to achieve this is by encouraging trust and commitment through fighting asymmetric information, for instance.

\section{CONCLUSIONS}

This work focused on the role that governments play in promoting SII. To that end, a comparative framework was put forward for the six largest economies of the Latin American region. The rationale for this approach lies in the growing importance that SII is having for financing development through the joint participation of both public and private agents.

In this regard, the growing body of literature dealing with the functioning of SII markets has identified two main issues. On the one hand, SII has been praised as one of the most appropriate mechanisms to foster socially oriented development because recipients are free to design which projects can have a more significant social impact on their communities. On the other hand, investors can "do well by doing good" in choosing how to direct their funds towards socially oriented projects, which can still have attractive financial returns.

Despite the known benefits of SII, Latin America has not yet been able to harness its potential. The main reason is enduring institutional weaknesses that have hampered the functioning of SII markets in the region. Another set of limiting factors relates to the chronic economic fluctuations that characterize the Latin American region. This has been further reinforced by the erratic policies several nations adopted over time, which further expanded SII investments and attracted foreign capital to these endeavors.

Our view is that policy failure is due to Latin American policymakers' inadequate implementation of the available policy tools. The analysis carried out here reveals that government officials are generally prone to apply a top-down approach for tackling social issues without considering alternative courses of action, such as encouraging the participation of social actors. Consequently, intended social goals are rarely achieved, and material and financial resources are generally wasted. To some extent, policy failures also obey the misunderstanding of the interplay of the participants in the SII ecosystem and what positions they occupy within this structure. For example, policymaking can be unsuccessful if the government seeks to supersede private investors or stricter regulations undermine social entrepreneurship.

Although appropriate policy-making can encourage SII markets, the role of the government in regulating these markets should not be overstated. History has shown that strict regulations within a weak institutional environment do not generally produce expected outcomes.

Yet, alternative solutions are not easy to design, let alone to implement due to enduring vested interests, especially those that have benefited from previously attempted policies (including private actors). We, therefore, think that a well-designed policy can encourage SII markets in Latin America if the region's governments start by reinforcing the institutional framework. For example, LAC governments can start by implementing more explicit and more transparent rules for diminishing asymmetric information regarding creating socially-oriented endeavors. The rationale is straightforward: with clear and transparent rules, markets like certainty and investors can gain confidence. For example, law enforcement can be enhanced to eradicate endemic public sector maladies in LAC, such as corruption. This particular example is worth stressing because bribery 
and fraud undermine the provision of better public services. One sensible way of combating corruption is by adopting the World Bank's Good Governance Indicators and diffusing the results. Finally, these practices can work more effectively with appropriate market regulations, such as those described in this chapter. Yet, these recommendations can only be viable if Latin America becomes aware and more receptive of SII benefits.

\section{ACKNOWLEDGMENTS}

The author acknowledges financial support from the Instituto Politécnico Nacional through the grant SIP-20200098.

\section{REFERENCES}

Abousleiman, I. A., \& Thompson, J. (2018) Mobilizing Private Finance for Development in Latin America and the Caribbean. Washington DC. World Bank.

Ács, Z. J., Szerb, L., Lafuente, E., \& Márkus, G. (2019) Global Entrepreneurship Index 2019. Washington DC: The Global Entrepreneurship and Development Institute.

Addis, R. (2016) The Roles of Government and Policy in Social Finance. In: Nicholls, A. J., Paton, R. \& Emerson, J. (Eds.), Social Finance. Oxford: Oxford University Press, pp. 383-459.

Allman, K. A., \& Escobar, X. (2015) Impact Investment: A Practical Guide to Investment Process and Social Impact Analysis. Hoboken NJ: John Wiley \& Sons.

Ashoka (2019) Sobre a Ashoka Brazil. Sao Paolo, Brazil. Report. [Available from: https://www.ashoka.org/pt-br/country/brazil

Bugg-Levine, A., \& Emerson, J. (2011) Impact Investing: Transforming How We Make Money while Making a Difference. Innovations: Technology, Governance, Globalization, 6(3), pp. 9-18. https://dx.doi.org/10.1162/INOV_a_00077

Calderini, M., Chiodo, V., \& Michelucci, F. V. (2017) The Social Impact Investment Race: Toward an Interpretative Framework. European Business Review, 30(1), pp. 66-81. https://dx.doi.org/10.1108/EBR-10-2016-0134

Cole, S., Gandhi, V. S., \& Brumme, C. R. (2018) Managing and Measuring Impact. Boston, MA: Harvard Business School Publishing. HBS Case No. 9-218-115.

Economic Commission for Latin America and the Caribbean (ECLAC) (2019) Social Panorama of Latin America 2018. Santiago de Chile. ECLAC.

Economist Intelligence Unit (EIU) (2019) Global Microscope 2019: The Enabling Environment for Financial Inclusion. New York. Economist Intelligence Unit.

Etchart, N., \& Comolli, L. (2013) Social Enterprise in Emerging Market Countries: No Free Ride. New York. Palgrave/Macmillan.

Fine, D., Pandit, V., Hickson, H., \& Tuinenburg, P. (2018) Catalyzing the Growth of the Impact Economy. New York. McKinsey.

Forcadell, F. J., \& Aracil, E. (2017) Sustainable Banking in Latin American Developing Countries: Leading to (Mutual) Prosperity. Business Ethics: A European Review, 26(4), pp. 382-395. https://dx.doi.org/10.1111/beer.12161

Fox, T., Ward, H., \& Howard, B. (2002) Public Sector Roles in Strengthening Corporate Social Responsibility: A Baseline Study. Washington DC. World Bank.

Glänzel, G., \& Scheuerle, T. (2016). Social Impact Investing in Germany: Current Impediments from Investors' and Social Entrepreneurs' Perspectives. Voluntas, 27(4), pp. 1638-1668. https://dx.doi.org/10.1007/s11266-015-9621-z

Harji, K., \& Jackson, E. T. (2012) Accelerating Impact: Achievements, Challenges and What's Next in Building the Impact Investing Industry. New York. The Rockefeller Foundation. 
Herman, R. P. (2010) The HIP Investor: Make Bigger Profits by Building a Better World. Hoboken NJ. John Wiley \& Sons.

Herman, R. P. (2013) Measuring the Impact of Social Entrepreneurship. In: Schultz, R. (Ed.), Creating Good Work: The World's Leading Social Entrepreneurs Show How to Build A Healthy Economy. New York: Palgrave Macmillan, pp. 61-66.

Kappen, J., Mitchell, M., \& Chawla, K. (2019) Institutionalizing Social Impact Investing: Implications for Islamic Finance. International Journal of Social Economics, 46(2), pp. 226-240. https://dx.doi.org/10.1108/IJSE-10-2017-0449

KPGM (2014) Unlocking the Value of Social Investment. Amsterdam. KPGM.

LAVCA (2018) The Impact Investing Landscape in Latin America: Trends 2016 \& 2017. New York. The Association for Private Capital Investment in Latin America (LAVCA).

Leme, A., Martins, F., \& Hornberger, K. (2014) The State of Impact Investing in Latin America: Regional Trends and Challenges Facing a Fast-growing Investment Strategy. São Paulo: Bain \& Company.

Nicholls, A. J. (2010) The Institutionalization of Social Investment: The Interplay of Investment Logics and Investor Rationalities. Journal of Social Entrepreneurship, 1(1), pp. 70-100. https://dx.doi.org/10.1080/19420671003701257

Nicholls, A. J., Nicholls, J., \& Paton, R. (2016) Measuring Social Impact. In Nicholls, A. J., Paton, R. \& Emerson, J. (Eds.), Social Finance. Oxford: Oxford University Press: pp. 253-281

Organisation for Economic Co-operation and Development (OECD) (2015) Social Impact Investment: Building the Evidence Base. Paris. OECD.

OECD (2019a) Latin American Economic Outlook 2019. Paris. OECD.

OECD (2019b) Social Impact Investment 2019: The Impact Imperative for Sustainable Development. Paris. OECD.

Schönherr, N., \& Martinuzzi, A. (Eds.) (2019) Business and the Sustainable Development Goals: Measuring and Managing Corporate Impacts. Cham. Palgrave Macmillan.

Thornley, B., Wood, D., Grace, K., \& Sullivant, S. (2011) Impact Investing: A Framework for Policy Design and Analysis. San Francisco: Insight.

Tuchman, G. (1994) Historical Social Science: Methodologies, Methods, Meaning. In: Denzin, N. K. \& Lincoln, Y. S. (Eds.), Handbook of Qualitative Research. Thousand Oaks CA: Sage, pp. 306323.

United Nations Conference on Trade and Development (UNCTAD) (2018) Selected Sustainable Development Trends in the Least Developed Countries. Geneva. UNCTAD.

Wiggan, J. (2018) Policy Boostering the Social Impact Investment Market in the U.K. Journal of Social Policy, 47(4), pp. 721-738. https://dx.doi.org/10.1017/S0047279418000089

Wilson, K. E. (2016) Investing for Social Impact in Developing Countries. In: OECD Development Co-operation Report 2016: The Sustainable Development Goals as Business Opportunities. Paris.

OECD, pp. 101-118. 